\title{
The Crisis of the Presence (1936-1944): The Antifascist Sacralization of Politics and the Rise of Magical Thinking during WWII
}

\author{
The Antifascist Turn in the Laterza Circle and the Continued \\ Sacralization of Politics
}

De Martino's years as an emergent scholar of religion culminated in what is oftentimes considered his best book, his magnum opus, a remarkably eclectic and interdisciplinary study entitled The World of Magic (1948). Scholarship has rightly remarked that Macchioro, whose work was characterized by his "surprising ability to live and think on a number of logical régimes,"1 was the decisive impetus for de Martino's broad thinking about magic. De Martino was particularly attracted to his teacher's work because of the latter's most famous book, namely Zagreus. Initially written in 1920 and republished in 1930 in a much-expanded version, Zagreus was not only a treatise on Greek mystery religion but also an attempt to offer a new method for its study. Specifically, in his hermeneutic effort to interpret the images discovered at Pompei as a liturgy of a ritual practice mimetically repeating the death and resurrection of the Dionysus in his Zagreus, Macchioro relied primarily on psychopathology and parapsychological findings. ${ }^{2}$ As to be expected, this curious blending of archeological materials from Ancient Greece and contemporary psychological materials, led to some surprising conclusions about the nature of orphic initiation: Macchioro interpreted the neophyte's "identification with God" as a process of actively splitting the self in order to achieve a "substitution of personality;"3 he compared key elements of the ritual performed by the new initiates, such as the perceptual fixation on points of light or on mirror, the repetitive sounds drums, or the use of perfumes, to techniques of hypnosis; ${ }^{4}$ and he weighed Proclus' comments on the "hallucinatory facts" experienced by the initiates in light of Charles Richet's Treatise on Metapsychics (1922). ${ }^{5}$

1 Charuty, Ernesto de Martino, 210.

2 Vittorio Macchioro, Zagreus: studi intorno all'orfismo (Firenze: Vallecchi, 1930), 169-285.

3 Macchioro, 233-37.

4 Macchioro, 233-37.

5 Macchioro, new edition: 183. Charles Robert Richet, Traité de Métapsychique (Paris: Félix Alcan, 1922). 
De Martino received the entire filing cabinet of his father-in-law's parapsychological research as a sort of "final consecration,"6 following his marriage to Anna on December 26, 1935. What has been called "the symbol for an entire life's work" for Vittorio, ${ }^{7}$ made a lasting contribution to virtually all of his disciple's major writings moving forward. This being said, in many ways, de Martino's new venture was also a step away from the prophetic guide of his student years. He not only shifted his thematic focus from civil religion to magic, but he also gradually widened the ethnographic realm of his inquiry to move beyond Christianity and ancient Greco-Roman religion, that is to say the Western civilization's cultural heritage. Instead, he started to embrace socalled "primitive" societies, which he chose to call "civilizations that are most distant from ours." 8 Relying on the bibliographic assistance of two of Italy's great anthropologists, Raffaele Pettazzoni and Renato Boccassino (1904-1976), he spent the years between 1938 and 1942 accumulating an impressive collection of "magical facts" from a wide array of diverse cultures and contexts. Commenting on this period of de Martino's life, scholars have spoken of a "gradual discovery of a new world" and a "fieldwork by correspondence," not unlike the early armchair anthropologists. ${ }^{9}$ De Martino, indeed, dove into many different worlds. Through the German ethnographer, Martin Gusinde, he visited the Selk'nam, yâmanas and kawéskar Indians of Tierra del Fuoco; with the Danish researcher Knut Rasmussen by his side, he imagined himself amongst the Inuit of Greenland; with the help of the missionizing Father Trilles, he walked the woods amongst the pygmies of the Equatorial Forest; with Paul Schebesta's study, he journeyed to the Ituri forests; and, finally, Sergei M. Shirokogoroff offered him a glimpse what it was like to live with the shamans of the Tungus.

Parallel to his disciple's expansion of horizons, Macchioro's position gradually degraded in the academic landscape of the Italian peninsula during the second half of the 1930s. When de Martino first contacted the dottore, he was an eminent figure in religious studies and in archeology, whose extravagant ideas, creative methodology, and innumerable engagements in foreign lands made him a propitious interlocutor for a young scholar in the "panorama of the small Italy of fascism."10 By the late 1930s, Macchioro was a different man in a rapidly transforming nation. The implementation of the racial laws in 1938

6 Andri, Il giovane Ernesto De Martino, 159.

7 Di Donato, "Preistoria di Ernesto de Martino," 29-30.

8 De Martino, Naturalismo e storicismo nell'etnologia, 283.

9 Gino Satta, "Le fonti etnografiche del 'Mondo magico," in Ernesto De Martino e la formazione del suo pensiero. Note di metodo, ed. Clara Gallini (Napoli: Liguori, 2005), 291; Charuty, Ernesto de Martino, 240.

Di Donato, "Introduzione," 22. 
represented a life-changing event, not unlike the years he spent during WWI twenty years earlier, when fighting alongside his fellow Italians. The new legislation not only forced Macchioro to retire from his archeological activities and to give up any hope of finally securing a professorship, but also led to a profound transformation of his personal and religious identity: Banned from academia, he converted to Catholicism, started writing novels, and took on the pseudonym of Benedetto Gioia.

His pen-name, of course, is a direct reference to what would become the most important intellectual point of reference for the remainder of de Martino's life, namely the idealist philosopher, Benedetto Croce (1866-1952). Of course, even the last name selected by Macchioro represents a calculated move as he used the name Gioia, which signifies "joy," to replaced Croce, which not only means "cross," but also brings with it a series of negative connotations, such as pain, burden, or curse. ${ }^{11}$ After his disciple is introduced to Croce in late 1937, at his residence in Villa Laterza in Bari, ${ }^{12}$ Macchioro tried everything to keep de Martino under his intellectual domain. His various strategies ranged anywhere from simply imploring him to "throw away this Crocean nonsense (baggianata),"13 to introducing him to his "unique Romanian disciple" Mircea Eliade, ${ }^{14}$ to publishing his novels under the name "Benedetto Gioa," to finally writing him a letter about a meeting with Croce himself during which the latter showed decisive openness to some of Macchioro's increasingly occult interests in cartomancy, dream divination, and so forth. ${ }^{15}$ The rupture, however, was inevitable and the master's heated letter in the closing days of 1939—one year

11 Consider, for instance, the expression croce e delizia ("cross and delight"), which is generally used when something is a mixed blessing, both a blessing and a curse, or something that involves both pleasure and pain. I thank the anonymous reviewer for this reminder and example.

12 Girolamo Imbruglia, "Tra Croce e Cassirer," in La contraddizione felice? Ernesto de Martino e gli altri, ed. Riccardo Di Donato (Pisa: Edizioni ETs, 1990), 97-98; Valerio Salvatore Severino, "Ernesto de Martino nel circolo crociano di villa Laterza: 1937-1942. Contributo a una contestualizzazione politica de il mondo magico," La Cultura 40, no. 1 (2002): 89-106.

13 Di Donato, "Preistoria di Ernesto de Martino," 35.

14 Di Donato, 32-33; Silvia Mancini, "Postface," in Le monde magique, by Ernesto De Martino (Paris: Les empêcheurs de penser en rond, 2003), 404-6; Gennaro Sasso, Ernesto de Martino fra religione e filosofia (Napoli: Bibliopolis, 2001), 88; Pietro Angelini, "Il rapporto tra Ernesto de Martino e Mircea Eliade," in Ernesto de Martino nella cultura europea, ed. Clara Gallini and Marcello Massenzio (Napoli: Liguori, 1997), 212.

15 This letter written on May 30 1939, half a year before their last and final correspondence, has been discussed extensively in recent years. Cf. Di Donato, "Preistoria di Ernesto de Martino," 35-38; Sasso, Ernesto de Martino fra religione e filosofia, 30-34; Charuty, Ernesto de Martino, 124; Andri, Il giovane Ernesto De Martino, 233-34. 
after the birth of his second grand-daughter Vera-offers the last evidence of their intense relationship.

Macchioro's adversary was indeed formidable. During much of the totalitarian regime of fascism, at least from 1924 until the end of the war in 1945, Croce held a unique position amongst Italian intellectuals as he was the only antifascist voice tolerated by Mussolini. After entering the so-called Villa Laterza circle, which formed in Bari around Croce, de Martino started to openly reject the fascist regime in the late $1930 \mathrm{os} .{ }^{16}$ Married to a Jewish woman and actively anti-fascist, he came to be marginalized by the fascist authorities and started to express increasingly radicalized views. In November 1942, he became a founding member of the Liberal-Socialist Party (Partito liberalsocialista) and that same year his name appeared on a blacklist of persons that are potentially damaging to the fascist regime. After being banned from teaching and losing his job, he went into hiding, spending the next two years in clandestineness in Cotignola, in the countryside around Ravenna, in the North of Italy. ${ }^{17}$ Yet, even though he became active in an antifascist circle of liberals associated with Benedetto Croce and the Laterza Publishing House in the year after his move to Bari in 1935, de Martino's thoughts and ideas remained steeped in religious sentiment and mystical rhetoric.

In 1936, de Martino sends Macchioro a "declaration of his faith in history," which has rightly been described as "a sacralization of history."18 Then, in 1941, de Martino crafted a manifesto of liberal-socialist faith, which formed the basis of a solemn oath sworn by the members of the Barese circle..$^{19}$ The final lines of the manifesto read as follows: "Thus, I swear, in the presence of the past generations that reached up to me, in the presence of the dead, the sacrificed, the aching, for love of liberty, in the presence of the future generations that

16 Some of the more prominent members of this group were Tommaso Fiore, Carlo Muscetta, Fabrizio Canfora, Michele Cifarelli, Michele Abbate, Domenico Loizzi, and Nicola Sansone. For more details on this period of his life, see Severino, "Ernesto de Martino nel circolo crociano di villa Laterza"; Charuty, Ernesto de Martino, $153 \mathrm{ff}$.

17 This period has remained a black hole in scholarship on de Martino, who himself rarely spoke about his participation in the Resistance. For a promising new study, which appeared only shortly before the completion of my manuscript, see Riccardo Ciavolella, L'etnologo e il popolo di questo mondo: Ernesto De Martino e la Resistenza in Romagna (1943-1945) (Milano: Meltemi, 2018). For a more general overview of the various stages of scholarship on this perioid, see Pietro Angelini, "L'anno Zero Di de Martino," Nostos 4 (2019): 9-49.

18 Conte, "Decadenza dell'Occidente," 498.

19 Domenico Loizzi, "Bari antifascista," in Studi storici in onore di Gabriele Pepe, ed. Gabriele Pepe and Giosuè Musca (Bari: Dedalo, 1969), 819-27; Severino, "Ernesto de Martino nel circolo crociano di villa Laterza." 
already start within me, here and today, [to render] their lives more human and more worthy."20

De Martino's anti-fascism was a religious undertaking that aimed at healing the civilizational crisis affecting his world with the ultimate goal of a complete utopian palingenesis. More specifically, "The Oath," redacted as anti-fascist manifesto, retained a series of distinctive traits of his earlier thinking: The definition of the cultural context as one of crisis and catastrophe, ${ }^{21}$ the mystical rhetoric of a universal Spirit and the individual responsibility for the good of unification and totality, ${ }^{22}$ the continuous lineage of Europe's two thousandyear history and his own responsibility for the future generations, ${ }^{23}$ the emphasis on fervor and activism rather than philosophical inactivity, ${ }^{24}$ the call for an evangelization of his political convictions, ${ }^{25}$ the apocalyptic and palingenetic ideas of rebirth, illumination, and revival, ${ }^{26}$ the celebration of soldier-hood and the call for constant battle, ${ }^{27}$ and the sacrificial rhetoric that culminates in presenting himself as Christ carrying the pain for humanity. ${ }^{28}$ In short, despite his political conversion, de Martino remained engaged in the missionizing project of his civil religion. Charuty pertinently described de Martino's project as a "paradoxical form of battle for secularity (laïcité), which presents itself as a religious struggle," and Mancini rightly commented that "the idea of civil religion and of civil symbolism never definitely disappears from the Demartinian reflection, not even after he takes his distance from the youthful fascism and his progressive political engagement on the left." ${ }^{29}$

Although it might sound surprising to find de Martino's underlying attitude unchanged despite his turn from fascism to liberalism and later socialism, the evident constancy of crisis and the need for recovery through radical action is anything but atypical of his age. Indeed, if the political aberrations of the twentieth century are seen through the lens of crisis, as "a disease of our own world," as Louis Dumont says, rather than the invention of specific

\footnotetext{
20 Ernesto De Martino, "Il giuramento," in Naturalismo e storicismo nell'etnologia, ed. Stefano De Matteis (1941; repr., Lecce: Argo, 1997), 261.

21 De Martino, 26o.

22 De Martino, 259.

23 De Martino, 259.

24 De Martino, 259.

25 De Martino, 26o.

26 De Martino, 261.

27 De Martino, 26o.

28 De Martino, 259.

29 Silvia Mancini, "Fra pensiero simbolico, religione civile e metapsichica: la storia delle religioni nel primo Novecento italiano," in Storia d'Italia, Annali 25: Esoterismo, ed. Gian Mario Cazzaniga (Torino: Einaudi, 2010), 644.
} 
people and nations, ${ }^{30}$ then the "cultural despair" was bound to produce similar responses. ${ }^{31}$ In the wake of Spengler's pessimistic reading of civilizational crisis, Europe was marked by a "fever of experiment in all political camps." 32 As a consequence, scholarship has gradually moved away from seeing the rise of fascism as an isolated event, investigating it instead as part of a larger rise of "totalitarianism." ${ }^{3}$ This shift of perspective in the wake of the "totalitarianism debate," which allowed critics to unite fascism and Stalinism under one umbrella term, enables us to make sense of the curious fact that de Martino's underlying thinking remained the same despite his shift in political selfidentification. Indeed, just as de Martino moved relatively fluidly between his early years as a fascist, towards Croce's liberalism, and then towards socialism, scholarship has clearly demonstrated that these political orientations were not independently existing entities, but rather systems that were embedded in a larger historical context of crisis and connected to each other in complex mutual relationships.

It has further been argued that liberal and socialist worldviews accommodated the rise of fascism ${ }^{34}$ and that the October Revolution and rise of socialism in Russia inflamed a reaction of the political right in the rest of Europe, thus contributing greatly to the rise of fascism. ${ }^{35}$ Even more, scholarship on totalitarianism has pointed to the fact that both fascism and Bolshevik socialism were equally engaged in a sacralization of politics. ${ }^{36}$ This also holds true for de Martino. In an article from 1944, he introduced a new religion, calling it the "Religion of Liberty," a purely immanent and this-worldly form of religion that is supposed to replace Christianity. He criticized the "young" that call out for the "moralization of political life." Their "unbridled activism without

30 Dumont, Essays on Individualism, ${ }^{1} 5^{-} 5^{2}$.

31 Anne Harrington, Reenchanted Science: Holism in German Culture from Wilhelm II to Hitler (Princeton: Princeton University Press, 1996), xxi-xxii.

32 H. Stuart Hughes, Consciousness and Society: The Reorientation of European Social Thought, 1890-1930 (Brighton: Harvester Press, 1979), 372.

33 Carl J. Friedrich, Michael Curtis, and Benjamin R. Barber, Totalitarianism in Perspectives: Three Views (London: Pall Mall Press, 1969); Henry Ashby Turner, Reappraisals of Fascism (New York: New Viewpoints, 1975); Juan José Linz, Totalitarian and Authoritarian Regimes (Boulder: Lynne Rienner Publishers, 2000).

34 Horst Junginger, Von der philologischen zur völkischen Religionswissenschaft: das Fach Religionswissenschaft an der Universität Tübingen von der Mitte des 19. Jahrhunderts bis zum Ende des Dritten Reiches (Stuttgart: Franz Steiner, 1999), 306-7.

35 Ernst Nolte, Der Faschismus in seiner Epoche: die Action française, der italienische Faschismus, der Nationalsozialismus (München: R. Piper \& Co., 1963); Ernst Nolte, Der Europäische Bürgerkrieg 1917-1945: Nationalsozialismus und Bolschewismus (Frankfurt am Main: Ullstein, 1987); Bernecker, Europa zwischen den Weltkriegen, 22-23.

36 Eric Voegelin, Die politischen Religionen (Stockholm: Bermann-Fischer Verlag, 1939); Bernecker, Europa zwischen den Weltkriegen, 31-32. 
scruple," he continued, "will lead to the dissolution with politics." Instead, he suggests that as long as Christianity, with its aspiration for moral guidance on principles beyond this life, is our civilization's primary religion, politics will continue to be "destined to break down to a simple conflict of power." 37 With these words, de Martino called his readers to return to the "religion of liberty" as their guiding principle, which would render political activity more morally conscientious. ${ }^{38}$ In all of his writings during these years, de Martino suggested that his religion of liberty, the "social gospel,"39 has to combat traditional forms of religion through disciplined order, action, and war; ${ }^{40}$ that this war is based on collectivity and solidarity amongst the people; ${ }^{41}$ and that Italians should take animus from the Russian example, which shows that even a dictatorship can lead to "real progress of liberty." 42 "Thus, when speaking of the religion of liberty," he wrote in the final years of the world conflict, "it is important to first and foremost be aware of the fact that we are concerned with a positive religion, that is a particular credo, which opposes all others and which combats all of them in a holy war, severe, daily, uncompromising, merciless." ${ }^{43}$

Although de Martino might have changed the label of his religious-political projects, the tendency to sacralize politics by elevating it to the status of a palingenetic energy expressed in struggle and community, which can save a civilization in crisis, remained a constant well into the 1940s. To underline how constant the fascination with the religious potential of political systems was in his thought, one only needs to look at the articles collected in Fury, Symbol, and Value, published in 1961. Here, de Martino cited contemporary Russian debates on socialist symbols, myths, and rituals, which — abundantly decorated with references to sacrifice, martyrdom, and struggle-demonstrate the full potential of socialism as a modern form of religion. ${ }^{44} \mathrm{He}$ admitted that the "religion of liberty" has failed, becoming "exhausted rather than growing," as it "got caught in ever more resounding contradictions," which were rooted in

37 Ernesto De Martino, "Politica, morale e religione," La voce dei giovani 1, no. 2 (July 1944): 1-2. See also, Cesare Milaneschi, "Ernesto de Martino e il Cristianesimo," Studi e materiali di storia delle religioni 51, no. 9 (1985): 249-50.

38 De Martino, "Politica, morale e religione.".

39 Ernesto De Martino, "Conoscerci," La voce dei giovani 1, no. 3 (August 1944): 2.

40 De Martino; Ernesto De Martino, "Noi e i cattolici," La voce del popolo 1, no. 16 (July 1, 1944): 1-2. Ernesto De Martino, "Collettivismo," La voce del popolo 1, no. 14 (April 20, 1944); De Martino, "Conoscerci."

41 De Martino, "Collettivismo"; De Martino, "Conoscerci."

42 Ernesto De Martino, "Della repubblica," La voce del popolo 1, no. 16 (July 1, 1944): 2; Ernesto De Martino, "Capitale e capitalismo," La voce del popolo 1, no. 16 (July 1, 1944): 2; De Martino, "Conoscerci." De Martino, "Furore in Svezia," 186. 
"limitations of classes," yet still professed that socialism offers currently the closest version to a "new unifying symbol."45 This "civil symbolism is in complete accordance with socialist humanism, capable of entirely filling the emptiness left by traditional forms of religion," and bases its legitimacy on the appeal "to the founding event of the October Revolution [...] as the passage from socialism to communism, as the liberation of colonial and semi-colonial people, as the socialist unification of our planet, and as the conquest of cosmic space." 46

\section{The Crisis of the Presence: Extreme States of Consciousness in Primitive Societies and the Shamanizing of Hitler in Europe}

Despite his continuous infatuation with political forms of religion-Croce known for his rigorous philosophical perspective-quickly became a great inspiration for the young Ernesto. Unlike his fascist past-which he never officially addressed-de Martino would years later nostalgically remember the years he came under Croce's tutelage, noting that "those were the years during which a small part of the Italian youth sought refuge in the austere and serene rooms of the Filomarino Palace to spell out anew the elementary human discourse, which was not possible elsewhere, sometimes not even in one's own family." ${ }^{\prime 7}$ Intellectually speaking, the first writing by de Martino that was formulated under the sway of Croce's historicist philosophy was Naturalism and Historicism in Anthropology, published in 1941 but written between 1937 and 1939. ${ }^{48}$ The book, dedicated to his university teacher Adolfo Omodeo, was published by the Laterza, a publishing house, whose history is closely tied to the antifascist and idealist thinking of Benedetto Croce. As Sasso noted, "almost everyone that has spoken" of de Martino's first book, noted that

45 De Martino, "Mito, scienze religiose e civiltà moderna," 77-78; De Martino, "Furore in Svezia," 187 .

46 De Martino, "Furore in Svezia," 188.

47 Ernesto De Martino, "Promesse e minacce dell'etnologia," in Furore simbolo valore (1962; repr., Milano: Feltrinelli, 2002), 86. Constructed in the fifteenth century, the Filomarino Palace was the residence of Benedetto Croce until he died in $195^{2}$.

48 The book, which de Martino wrote in Bari, starting in 1937, was printed in 1940 and finally made available in libraries in 1941. After more than fifty years, it has finally been republished by Stefano de Matteis in 1997. I will cite from this edition. De Martino, Naturalismo e storicismo nell'etnologia. The book has not yet been translated into English. The best English analysis of this text is to be found in a writing by an expert on Fascism from UC Berkeley, who I repeatedly cite in the second chapter of this dissertation: Simonetta Falasca-Zamponi, "Of Tears and Tarantulas: Folk Religiosity, de Martino's Ethnology, and the Italian South," California Italian Studies 5, no. 1 (January 1, 2014): 43-45. 
it "presents the character of the Crocean orthodoxy,"49 and the author himself would later describe it as a "book written and conceived in the furrow of the most orthodox Crocean historicist tradition."50 The book was a great success amongst the Italian intelligentsia, provoking a flood of positive reviews and reactions. ${ }^{51}$

In Naturalism and Historicism, de Martino used the stimulus of Croce's historicism to critique anthropological currents of thought that he defined as "naturalist:" The pre-logism of Lévy-Bruhl, the sociology of Durkheim, and the historical-cultural school of father Schmidt. In other words, de Martino dismembered the generalizing anthropological schools brought to Italy from abroad with the sharpest scalpel available to the Italian mind, namely historicist thinking: "Anthropology is the story of civilizations that are most distant from our Western one. As such it is by no means an autonomous science with its own methodologies, but constitutes the empirical—and hence approximate-edge of a sphere of possible historical research."52 Despite its immediate success, Naturalism and Historicism in Anthropology was soon to be forgotten by Italian academia. ${ }^{53}$ Today's scholars even argue that it is "little more than a derivative scholastic product," ${ }^{24}$ or just plain "unreadable." 55 In retrospect, the book's fortune was also impacted by the unfavorable political climate in which its author found himself as the Second World War ramped up.

However, de Martino did not let this hostile environment deter him from his mission. He continued to work tenaciously on his intellectual endeavors, which would finally culminate in his second book, The World of Magic. Although published only in 1948, it was mostly written on his portable Olivetti typewriter during his time in Bari and his years in hiding in the Ravennate. The dedication reads: "To my Anna, who has saved the manuscript of this work

Sasso, Ernesto de Martino fra religione e filosofia, 1. Cases, "Introduzione"; Giuseppe Galasso, Croce, Gramsci e altri storici (Milano: Il saggiatore, 1968).

$5^{\circ} \quad$ Ernesto De Martino, "Intorno a una storia del mondo popolare subalterno," Società 5 (1949): 411-35. I'm citing from a republished edition in 1977: Ernesto De Martino, "Intorno a una storia del mondo popolare subalterno," in Antropologia culturale e questione meridionale: Ernesto de Martino e il dibattito sul mondo popolare subalterno negli anni 1948-1955, ed. Carla Pasquinelli (La Nuova Italia, 1977), 71.

We have almost immediate reviews by Omodeo, Antoni, Cantoni, and Pettazzoni and later ones by Cesare Pavese e di Giuseppe Cocchiara. Furthermore, it is clear that Croce, after receiving a personal copy from de Martino himself, has read the book as well. De Martino, Naturalismo e storicismo nell'etnologia, 225 .

53 Although the book has been reedited by Stefano de Matteis and the publisher Argo, it still remains his least respected work. De Martino, Naturalismo e storicismo nell'etnologia.

54 Cases, "Introduzione," ix.

55 Charuty, Ernesto de Martino, 221. 
out of the ruins of Cotignola." The World of Magic, which, as one annotator observed so eloquently, looks like "a 'perfidious collage': fruit of six years of assiduous reflection and reconsiderations, but also of escapes, relocations, and rescues," receives its final structure in the months after the war. ${ }^{56}$ Despite de Martino's effort to integrate his long journey into a coherent whole, the book appears nevertheless fraught with internal tensions.

On the one hand, as I have shown elsewhere, Ernesto's earlier investigations into magic were dedicated to the obsessive collection and categorization of ethnographic and parapsychological facts and states of consciousness, independently of their cultural-historical context. ${ }^{57}$ On the other hand, his later thinking displayed the opposite procedure, namely the historicization of this data. The second chapter of The World of Magic is central, not only for its position within the book, but also for its intellectual merits. In arguing that magic plays a central role in the solid establishment of humanity's uncertain, fragile, threatened presence as an individuated self, his thinking moved into its "theoretically highest" realms. ${ }^{58}$ Looking back a decade later, de Martino himself perceived a rupture with his previous ideas, noting that it is only in the second chapter of his composition that he implements a historicization of primitive magic by offering a "sketch of a general theory of magic as a well-defined historical world." 59

Putting the person into the center of his historical-cultural study of magic, de Martino argued that the true power of magic lies not in the production of specific phenomena and states of consciousness but in the drama of the "risk and redemption of the presence." 60 There is no doubt that the theory of "the crisis of the presence" (la crisi della presenza) is one of Ernesto de Martino's most important contributions to the study of religion. Studying primitive societies, he argued that they rely on magic in order to defend themselves against the crisis of the presence-a loosely defined state in which individuals and communities lose their identity and their ability to act and respond to their surroundings. Apart from a few scattered insinuations - where he described it

56 Pietro Angelini, Ernesto de Martino (Roma: Carocci, 2008), 42.

57 Flavio A. Geisshuesler, "A Parapsychologist, an Anthropologist, and a Vitalist Walk into a Laboratory: Ernesto de Martino, Mircea Eliade, and a Forgotten Chapter in the Disciplinary History of Religious Studies," Religions 10, no. 304 (2019): 1-22.

58 Placido Cherchi and Maria Cherchi, Ernesto de Martino: dalla crisi della presenza alla comunità umana (Napoli: Liguori, 1987), 29.

59 Ernesto De Martino, "Crisi della presenza e reintegrazione religiosa," Aut aut 31 (1956): 17.

6o Ernesto De Martino, Il mondo magico: prolegomeni a una storia del magismo (1948; repr., Torino: Bollati Boringhieri, 2012), 110. 
as the "soul" (anima), ${ }^{61}$ as "being-there" (esserci), ${ }^{62}$ and as "the feeling of individual unity"63_-de Martino avoided substantial definitions of the concept of "presence" (presenza). Instead, almost all of the references to presence in The World of Magic are either related to the risk of being lost or to the potential of its redemption. The idea that the presence receives its significance in between crisis and redemption, indeed, would remain stable throughout the rest of his life. In posthumously published notes, we read of the crisis of the presence as both a "radical losing oneself," a "radical risk of alienation," a "total annihilation of man," and an "institutional program of interruption (arresto), of configuration, and of recovery of the self-alienating (alienarsi) as mere crisis."64

Unlike in modern societies, magic is a necessary phenomenon in extraEuropean cultural realities because the sense of self is fragile, unstable, and exposed to the constant risk of being lost. Looking at specific states of consciousness described in primitive societies, such as latah, olon, or amok, he remarked that they are the "polariz[ation] of the presence in a certain content" or the "collapse of the distinction between the presence and the world." Ultimately, so de Martino concluded, their true significance lies in the fact that in primitive societies the presence is in a constant state of crisis, marked by "fragility," "loss," and "abdication." 65 The self in magical societies, so he would deepen his reflections in the following years, is an expression of "real human precariousness in the world,"66 it is "a presence that is not decided and guaranteed, but rather fragile and unstable, and thus continually exposed to the risk of not preserving itself in light of becoming." 67

The presence, however, would have hardly been de Martino's concept if it did not involve some sort of reflection on his own civilization that reached well beyond his studies of other cultures. Drawing on his earlier studies of the rupture of modernity, such as his interpretation of secularization and scientification, de Martino knew well that Western society differs from that of nonEuropean peoples because it conceives at least of the possibility of a stable self. Our modern "Western experience" of the self as a stable and autonomous entity,

\footnotetext{
$61 \quad$ De Martino, $75,76,77,79$.

62 De Martino, 75, 79, 129, 16 o.

63 De Martino, 207.

64 De Martino, La fine del mondo, 451.

65 De Martino, Il mondo magico, 72-73.

66 Ernesto De Martino, "Etnologia e cultura nazionale negli ultimi dieci anni," Società 9, no. 3 (September 1953): 315, 322.

67 Ernesto De Martino, "Angoscia territoriale e riscatto culturale nel mito Achilpa delle origini. Contributo allo studio della mitologia degli Aranda," in Il mondo magico: prolegomeni a una storia del magismo (1948; repr., Torino: Bollati Boringhieri, 2012), 227.
} 
de Martino explained, is a "relatively recent" achievement that separates us historically from other cultures. ${ }^{68}$ De Martino pointed to Greek philosophy, ${ }^{69}$ to Christianity, ${ }^{70}$ and to Kant, ${ }^{71}$ to explain why our presence, unlike the presence in primitive societies, is marked by givenness and stability. On the other hand, de Martino was fully aware that since "the being-there of the person emerges as a mediated result ... as a cultural good — created through struggles, dangers, defeats, compromises, victories" 72 - the presence is a work in progress that needs to be sustained because it is always susceptible to be lost again. In a long footnote in the very heart of his book, de Martino cautions his readers:

It is necessary to briefly warn that there are, even in our civilization, "marginal situations" [...] in which these forms [of the crisis of the presence] can keep themselves vital, or rather produce themselves anew [...]: It suffices to think about the magical traditions still alive among our peasant populations, about the magic of the spiritist circles, and about [the magic] that is related to specific psychopathic states, such as psychasthenia, schizophrenia, and paranoia. In all of these cases we have to do with a persisting and reproducing, in more or less authentic forms, of the modes of the magic reality and of the correlative existential drama [...]. Moreover, also the educated and "normal" man can, in his daily life, be more or less fleetingly touched by these archaic realities. The fact that this reproduction of the magic reality is possible even for the Western, educated man, indicates how the established and guaranteed presence is a historical good, and, as such, is $[\ldots]$ revocable. ${ }^{73}$

In light of such comments, de Martino's reflections on the crisis of the presence have rightfully been tied to the specific socio-political context that surrounded him. Already in 1979, Carlo Ginzburg placed The World of Magic next to Dialectic of the Enlightenment (1947) by Theodor Adorno and Max Horkheimer and Fear of Freedom (1946) by Carlo Levi, grouping them together under the category of "the books of the year zero."74 The year 1944, so scholarship has since argued, was the apex of the Second World War and Nazi-fascist rule, leading to a

\footnotetext{
68 De Martino, Il mondo magico, 76.

69 De Martino, 156.

70 De Martino, 157.

71 De Martino, 159.

72 De Martino, 161.

73 De Martino, 129.

74 Carlo Ginzburg, “La fine del mondo’ di Ernesto de Martino," Studi storici 40, no. 1 (1979): 239. Carlo Levi, Paura della libertà (Torino: Einaudi, 1946); Max Horkheimer and Theodor
} 
collective crisis of catastrophic proportions that threatened the very existence of Europe as a continent. ${ }^{75}$ Years later, in "Myth, Religious Studies, and Modern Civilization," de Martino expressed this threat to the existence of his culture by drawing on the ideas of two other central figures in the twentieth-century study of religion, namely Sigmund Freud and Carl Gustav Jung.

Our fathers had taught us that Europe had decidedly embarked upon the royal road of progress and reason. At this point nothing could put the cultural achievements, accumulated during almost two thousand years of European history, into danger. But now, the "dark side of the soul" regained dominion and seemed to reunite with the "primitive world," which was not yet sufficiently exorcised. Traveling on the road of neurotic regressions of his Viennese clientele, Dr. Freud believed to discover some concurrency between these regressions and the cultural institutes of anthropological civilizations. Likewise, Jung believed to be able to edify his theory of archetypes of the collective unconscious on the bases of other concurrencies between symbols of the dream life, the phantasies of the psychotic [patients], and the figures of the myth. Regardless of the judgment cast upon these psychoanalytic theories, they documented at least that much: the solemn exorcism of traditional reason had not been entirely successful and the ciphered depths of the soul reappeared hand in hand with the ciphered cultures of our planet to pose a problem for modern civilization. ${ }^{76}$

His boldest book must be analyzed in the socio-political context that surrounded him. In an earlier version of this article published in 1953, de Martino explicitly prefaced this passage by a reference to WWII, noting that "these were the years during which Hitler shamanized in Germany and in Europe."77 During this time, the Neapolitan historian of religion, living in hiding, experienced his very personal crisis of hunger, cold, and death. Taking refuge in the house of Rosita Parrà, the wife of Vittorio Macchioro, it was in Cotignola that he joined in the activity of one of the many small clandestine groups of the Italian resistance movement (Resistenza), living an underground existence made up of

W Adorno, Dialektik der Aufklärung: philosophische Fragmente (Amsterdam: Querido, 1947).

75 Ernesto Galli della Loggia, "Apocalissi culturali e cultura nazionale," in Dell'apocalisse. Antropologia e psicopatologia in Ernesto de Martino, ed. Bruna Baldacconi and Pierangela Di Lucchio (Napoli: Guida, 2005), 32.

76 De Martino, "Promesse e minacce dell'etnologia," 86.

77 De Martino, "Etnologia e cultura nazionale negli ultimi dieci anni," 314. 
anti-fascist propaganda and militancy. Politically, he was particularly involved to the Italian Labor Party (Partito italiano del lavoro, PIL) and he wrote fervently in favor of a new religion of liberty (religione della libertà) in journals such as La Voce del popolo and La Voce dei giovani. ${ }^{78}$ From the time of Mussolini's arrest and the fall of fascism on July 24, 1943, until the end of the war, the region along the river Senio became one of the most violently contested areas in all of Italy and de Martino found himself under constant threats of the raids of the German ss and the Gestapo, as well as the squads of the newborn Italian Social Republic (Repubblica Sociale Italiana) ${ }^{79} \mathrm{In}$ fact, after Mussolini's proclamation of this second Italian state-which is more commonly known as the "Republic of Salò" (Repubblica di Salò)—on September 18 1943, Italy's war became a civil war in which Italians would fight amongst themselves.

\section{3 \\ The Dark Side of the Soul Resurfaces in Religious Studies: The Split between the Insider-Phenomenological and the Outsider-Explanatory Approaches}

After the war ended, continuing to pendulate in between crisis and redemption, de Martino returned to Bari to complete his research and finish his book. ${ }^{80}$ Since its publication, it has been read in Italy and abroad - translated in no less than seven languages ${ }^{81}$ — and is by many considered his "most innovative and current work." ${ }^{82}$ It has rightly been called his "masterpiece" (capolavoro). ${ }^{83}$ But why was this period such a critical moment in the history of the twentieth

78 Ernesto De Martino, "Intorno alle 'Dottrine sociali delle chiese e dei gruppi cristiani,"” La Nuova Italia XVI, no. 5-6 (June 1943): 51-53; De Martino, "Collettivismo"; De Martino, "Noi e la religione”; De Martino, "Capitale e capitalismo"; De Martino, "Della repubblica”; De Martino, "Noi e i cattolici"; De Martino, "Conoscerci"; Ernesto De Martino, "Danaro e banche," La voce del popolo 1, no. 17 (August 1944).

79 Cesare Bermani collects a series of testimonies that give the reader a vivid sense of the dangers that de Martino was in during those months of his life. Bermani, "Tra furore e valore: Ernesto de Martino."

8o De Martino met Pavese in the spring of 1943 in Rome, where the editor Einaudi recently opened an office in Via Monteverdi. See also, Pietro Angelini, "Prefazione," in Dal laboratorio del mondo magico. Carteggi 1940-1943, ed. Pietro Angelini (Lecce: Argo, 2007), 9.

81 The book has been translated into English, French, Spanish, Czech, Hungarian, Polish. According to Ginzburg, it has also been translated into Japanese, but I could not verify that yet.

82 Adriano Santiemma, "La religione tra phainómenon e genómenon, tra natura e cultura," in Le religioni e la storia: a proposito di un metodo, ed. Gilberto Mazzoleni and Adriano Santiemma (Roma: Bulzoni, 2005), 59.

83 Mustè, La filosofia dell'idealismo italiano, 193. 
century for de Martino? What was the difference between 1918 and 1944? If de Martino was long convinced that his own continent suffered from a massive civilizational crisis, the crisis of the presence nourished these reflections with new energy - ultimately leading him to identify the realm of science as the place where our presence was most threatened. In other words, if WWI represented the collapse of the progressivist world-view, throwing the Western world into a civilizational crisis, it was in the following decades that the crisis reached its fullest extent by embedding itself within scientific thinking itself.

The scientific reactions to the crisis of the self, were indeed oftentimes radical in nature. If the most extreme example of this loss of certitudes into reality might be Oswald Spengler's claim that even mathematical numbers are ultimately relative, ${ }^{84}$ Edmund Husserl's The Crisis of the European Sciences represents a good illustration for the crisis of the self. In this piece, written in the last years of his life between 1934 and 1937, the German phenomenologist argued that the crisis of positivist science ultimately led to a crisis of meaning of humanity and its cultural life. His response, as we all know, was the establishment of a transcendental phenomenology that would salvage not only the status of reason, but also of the subject.

De Martino, who was convinced that the discipline of religious studies was particularly sensitive to the divisive forces at work within the crisisconsciousness of the modern West, believed that the crisis not only afflicted the realm of science but actually infiltrated it from the inside. One of the key categories through which the crisis of the self was internalized in the scientific study of religion was "magic." While it is well known that already Tylor, Frazer, and Malinowski saw magic as the origin of science, ${ }^{85}$ de Martino was less interested in substantive definitions of the concept, but rather its relational importance as a form of radical alterity. ${ }^{86}$ Wouter Hanegraaff has recently argued that modernity was not only defined by the split between "religion" and the realm of "the secular," but also a "third domain, referred to by such terms as 'magic' or 'superstition.".87

84 Reinhard Laube, Karl Mannheim und die Krise des Historismus: Historismus als wissenssoziologischer Perspektivismus (Göttingen: Vandenhoeck \& Ruprecht, 2004), 41; Cathryn Carson, "Method, Moment, and Crisis in Weimar Science," in Weimar Thought: A Contested Legacy, ed. Peter Eli Gordon and John P. McCormick (Princeton: Princeton University Press, 2013), 193; Bambach, "Weimar Philosophy and the Crisis of Historical Thinking," 138.

85 Randall Styers, Making Magic: Religion, Magic, and Science in the Modern World (New York: Oxford University Press, 2004), 125-26, 139-40.

86 Jonathan Z. Smith, Relating Religion: Essays in the Study of Religion (Chicago: University of Chicago Press, 2004), 216-19; Styers, Making Magic, 145-46.

87 Hanegraaff, "Reconstructing 'Religion' from the Bottom Up," 577. 
Because this fact goes unrecognized, what usually happens is that the third term is tacitly removed from the equation instead of being included under the umbrella of "religion." The deep irony is that by thus treating the third term as largely irrelevant to the concept of "religion," thereby rendering it invisible, even contemporary deconstructionists end up perpetuating the very same Christian-Protestant ideologies whose legacy they are trying so hard to deconstruct! If the triadic perspective continues to make intuitive sense to us even today, this is because our intellectual culture has inherited the profound disdain for "pagan/ idolatrous/ magical/superstitious" beliefs and practices that has always been typical of orthodox (and most particularly Protestant) Christians. Secular thinkers who embrace the values of rationality and science have unwittingly adopted the same normativities from their Protestant forebears. In short, $[\ldots]$, both Christianity and secular modernity define their very identity against this "Other." 88

De Martino would have fully agreed with the expert of Western esotericism. While his theory of de-historification was concerned with the logic of magic, he maintained, throughout his career, active research projects into how historians of religion have dealt with magic. "Western civilization," so he most famously wrote in Magic and Civilization, "has come to shape itself as modern civilization through an assiduous anti-magical polemic (polemica antimagica)." ${ }^{89}$ One consequence of the "Hellenic-Christian anthropology and the anti-magical polemic innate in our civilization," he remarked in The World of Magic, is that "being-there appears to us now as [...] given to man by nature, [as something] that he did not do, and therefore as the unknowable, the irrational, the mysterious par excellence."90 In other words, de Martino was concerned that the existence of the discipline of religious studies is itself indebted to our culture's attitude towards magic as something radically other. Similar to contemporary researchers of identity politics, such as Gerd Baumann, de Martino realized that alterity is structured along the lines of a binary oppositions ("good" vs. "bad"), which is itself subject to reversal as rejection can turn into fascination, and vice versa. Specifically, de Martino also grew more aware of the fact that

88 Hanegraaff, 595-96. As an anonymous reviewer rightly noted, the distinction between religion and magic is not simply a modern phenomenon, as this distinction can be traced all the way back to the Ancient Greeks and Romans.

89 Ernesto De Martino, Magia e civiltà (Milano: Garzanti, 1962), 5-6. The notion of the polemic is omnipresent in the book. In the roughly three dozen pages written in his own pen, de Martino uses the term "anti-magical" no less than twenty-four times. 
the polemic surrounding magic gave rise to two radically opposed and mutually exclusive perspectives that ultimately account for the split within the discipline of religious studies and anthropology itself, namely what I called the insider-phenomenological and the outsider-explanatory approaches.

It is a unique fact that our age knows not only a copious literature related to the revaluation of the sacred as a category, but also an equally massive literature, in which the decline of religious life in the modern world is being discussed: One could say that the sacred has never before been so eruditely defended as a fundamental value of human existence as in our period, while at the same time, the realization of the eclipse, the agony, or even the death of the sacred has never before been as intense as today. ${ }^{91}$

The former of these is already well known to the reader as it was the primary focus of the preceding chapter. Indeed, isn't Eliade's politics of nostalgia a search for that which is magically "other"? In Magic and Civilization, de Martino explained that in certain currents, "magic thought appeared in just as authentic a manner as rational thought." "This perspective," so de Martino warned, is also problematic precisely because "the Western opposition between magic and reason has come to lose its meaning, the aut-aut resolved itself in the indifference of an et-et that left open the possibility to return to irrationalistic ideals of life and traditions." Eliade's nostalgic tendency, which was based on something akin to remembering the way things were before the magical worldview was abandoned by Western society, involves "the lack of loyalty to this history of our own civilization." 92

By contrast, the perspective of the outsider-explanatory approach vilified and rejected the alterity of magic. De Martino called this the "anti-magical polemic of scientific thought" and recognized it primarily in the writings of Frazer, Durkheim, Malinowski, Freud, and Lévi-Strauss. ${ }^{93}$ In these works, the Italian thinker found traces of the process of othering that has created modern Western identity. While he concluded his book by noting that all of them remained "unknowingly prisoners of some immediate themes of the anti-magical polemic of Western civilization," ${ }^{94}$ de Martino was particularly drawn to the work of Claude Lévi-Strauss because his radical opposition to the insider-phenomenological approach perfectly illustrated the internalized

$\begin{array}{ll}91 & \text { De Martino, "Mito, scienze religiose e civiltà moderna," } 76 . \\ 92 & \text { De Martino, Magia e civiltà, 213-14. } \\ 93 & \text { De Martino, } 79 . \\ 94 & \text { De Martino, 213. }\end{array}$ 
crisis within the discipline of religious studies. It is well known that the French structuralist was radically opposed to any form of nostalgia, primitivism, phenomenology, or existentialism-in short, all the currents that collude in the insider-phenomenological approach to religion. As Ivan Strenski has argued,

Lévi-Strauss's "mythology" remains emotionally or even imaginatively inaccessible to any exotic primitivist industry: structures are impersonal and abstract, not "warm," not rich with images. Despite Lévi-Strauss's personal prestige on the public intellectual scene in France as a kind of modern philosophe, structural mythology itself has never become a durable cultural fad in the way that theories of Joseph Campbell, Mircea Eliade and Carl Jung, as set out in their far more popular works, have. ${ }^{95}$

Lévi-Strauss himself did not hold back with critique of the phenomenological current in religious studies, attacking specifically its tendency to set apart the sacred as a special realm of meaning. He is trenchant in his analysis of thinkers who "believe too readily that they have succeeded in grasping, beyond their own preconceptions, the ideas of the indigenous people [as] their descriptions are too often reduced to a phenomenology." ${ }^{\prime 96}$ In the fourth volume of his Mythologiques, entitled The Naked Man (1971), we find a similarly "deflationary" position typical of the outsider-explanatory approach. Here, the French anthropologist argued that much of contemporary scholarship is "imbued [...] with mysticism," in search of a "mythology to be full of hidden meaning." ${ }^{97} \mathrm{He}$ suggests that while he considers the "religious field as a stupendous storehouse of images that is far from having been exhausted by objective research," he nonetheless insists that "these images are like any others." 98

As mentioned, scholarship has not neglected to notice this anti-essentialist approach in commenting on Lévi-Strauss' work. Strenski, for instance, has observed that the French structuralist is frequently critical of Eliade, specifically because of his "reputation for seeing myths as expressions of religious nostalgia for the primordial beginnings, as declarations of a primitive ontology." ${ }^{\prime 9}$ In the continuation of the above-cited passage, Lévi-Strauss took

\footnotetext{
95 Strenski, Four Theories of Myth in Twentieth-Century History, 163.

96 Claude Lévi-Strauss, "Comparative Religions of Nonliterate Peoples," in Structural Anthropology Volume II (Chicago: University of Chicago Press, 1983), 67.

97 Claude Lévi-Strauss, The Naked Man: Introduction to a Science of Mythology IV (New York: Harper \& Row, 1981), 645-46.

98 Lévi-Strauss, 639.

99 Strenski, Four Theories of Myth in Twentieth-Century History, 157.
} 
a direct stance against the frequently nostalgic orientation of the insiderphenomenological approach:

The fallacious complaint that the myths have been impoverished hides a latent mysticism, nourished in the vain hope of the revelation of a meaning behind the meaning to justify or excuse all kinds of confused and nostalgic longings, which are afraid to express themselves openly. We have to resign ourselves to the fact that the myths tell us nothing instructive about the order of the world, the nature of reality or the origin and destiny of mankind. We cannot expect them to flatter any metaphysical thirst, or to breathe new life into exhausted ideologies. ${ }^{100}$

It has been repeatedly stated that French structuralism formed its program based on following a "scientific approach." ${ }^{101}$ Lévi-Strauss, expert of the indigenous peoples of South and North America, is no exception as his goal can be summed up as the development of a "full-scale science of culture."102 As Paul-François Tremlett, in one of the rare monographs dedicated to LéviStrauss as a scholar of religion, commented, the French thinker "consistently privileged science and made use of science as a special discourse to give his own work authority, and as a means of legitimating an alliance of social anthropology with structural linguistics."103

Reader of the classic structuralist writings of Lévi-Strauss, particularly Elementary Forms (1949), Structural Anthropology (1958), and Savage Thought (1962), ${ }^{104}$ de Martino was also fascinated by how structuralist linguistics can teach us about unconscious mechanisms at work in culture. ${ }^{105}$ As François Dosse, in his careful study of structuralism's rise and decline in France, has unveiled, structuralism dominated the French intellectual life, representing

100 Lévi-Strauss, The Naked Man, 639.

101 Agnes Heller, "Death of the Subject?," in Constructions of the Self, ed. George Levine (New Brunswick: Rutgers University Press, 1992), 270; François Dosse, History of Structuralism. Vol. 1: The Rising Sign, 1945-1966 (Minneapolis: University of Minnesota Press, 1997), 159, 191, 382-383, 387, 390-391; François Dosse, History of Structuralism. Vol. 2: The Sign Sets, 1967-Present. (Minneapolis: University of Minnesota Press, 1997), 47, 45o.

102 Roberts, Nothing but History, 42.

103 Paul-François Tremlett, Lévi-Strauss on Religion: The Structuring Mind (Sheffield: Equinox Publishing, 2008), 22. Strenski describes his approach as a "thoroughgoing naturalism." Strenski, Four Theories of Myth in Twentieth-Century History, 131.

104 De Martino, La fine del mondo, 266-68, 403-13, 623-27, 688-89. See also, Ernesto De Martino, "Etnologia e civiltà moderna," Cultura e Scuola 2 (September 1964): 14.

105 De Martino, La fine del mondo, 405. 
"the koine of an entire intellectual generation."106 While structuralism has found a broad range of intellectual expressions - the Marxist theory of Louis Althusser, the literary studies of Roland Barthes, the philosophy of Michel Foucault, the psychoanalysis of Jacques Lacan, the comparative philology of Georges Dumézil, or the literary theory of Pierre Macherey-de Martino encountered and appreciated the structuralist project primarily because of the monumental work of the anthropologist Claude Lévi-Strauss. ${ }^{107}$ His attitude towards the structuralist science of Lévi-Strauss is favorable. He believed that the history of religions as he practices it should be "enriched by the instances ripened in the course of the development of sciences such as sociology, psychiatry, cultural psychiatry, folklore, traditional anthropology, anthropology, and linguistics." ${ }^{108}$ De Martino recognized that the approach proposed by Lévi-Strauss is premised on a "reduction" - particularly he speaks of a "reduction to the common and to the unconscious" of myths-and described the operation as an "opportunity" that has "value."109

The Savior of the European Sciences: The Redemption of the Presence and the Unifying Power of Magic

It is here that de Martino's work reveals its redemptive side. Indeed, just as Lévi-Strauss' structuralism allows the scholars of religion to penetrate what lies behind the veil of consciousness in order to bring to light the underlying structure and meaning of the unconscious, The World of Magic was a means to gain a deeper understanding of the crisis afflicting Western civilization. In both cases, this unveiling of latently active unconscious dynamics creates the value of understanding and self-awareness, which are the foundations for any attempt to transcend the crisis of the presence.

Placido Cherchi, a student of de Martino during the last years of his life at the University of Cagliari, argued that the years of the war were not only those of the apocalypse but also "the starting point of a historical re-founding."110 In his insightful book, the anthropologist argues that the experience of the

\footnotetext{
106 Dosse, History of Structuralism. Vol. 1: The Rising Sign, 1945-1966, xxiv.

107 John Storey, Cultural Theory and Popular Culture: An Introduction (London: Routledge, 2012), 239.

108 De Martino, La fine del mondo, 406-7.

109 De Martino, 413.

110 Placido Cherchi, Il signore del limite. Tre variazioni critiche su Ernesto de Martino (Napoli: Liguori, 1994), 34 .
} 
war should be seen as a "ritual of puberty, a terrible initiatic event,"111 as de Martino's own "rite of passage."112 Although generations of Italian intellectuals, from Croce to Arnaldo Momigliano, were right in acknowledging the "irreparably destroyed" political, economic, and moral foundations that "Italian generations had constructed for a century" and the "never fully to be overcome [...] changes of cultural interests and orientations,"113 de Martino continued to cultivate a decisively palingenetic vision of history. Although his writings made it obvious that the distant world of primitives was in reality threateningly close - or even within himself and his own culture-de Martino remained optimistic and regarded crisis as the basis for rebirth of Italy. Most recently, Ulrich Van Loyen has pointed to this salvific component of de Martino's book on magic. I wholeheartedly agree with my German colleague's comment that one of the most important dimensions of de Martino's magnum opus "lies in its intention [...] to save Europe."114 In some passages of his unpublished autobiography, de Martino intentionally put on the cloak of the cultural savior, only to reveal that it is sowed into his very skin in the form of an "atypicalness" that predestined him for his calling:

Without relieving myself of even the smallest bit of responsibility, it is to be observed that in the great periods of crisis and renovation of civilization; when old connections are dismantled, and new ones disclose themselves, yet without being able to say that a new order has yet arisen, one records a spike in atypical men that violate all the norms. I believe to be one of these men.115

Although de Martino was, without a doubt, a crisis-thinker, his work was never giving into pessimism, but instead regarded crisis as a productive motor for cultural innovation. Already in Naturalism and Historicism, de Martino called upon the "historian" in order to rebuild a new world out of the rubble of crisis: "Concerning the historian's role in the drama and the task (compito) that is his,

\footnotetext{
111 Cherchi, 25.

112 Cherchi, 33 .

113 Benedetto Croce, Quando l'Italia era tagliata in due; estratto di un diario, luglio 1943giugno 1944 (Bari: Laterza, 1948), 44; Arnaldo Momigliano, "Per una storia delle religioni nell'Italia contemporanea: Antonio Banfi e Ernesto de Martino tra persona e apocalissi," in La Contraddizione felice?: Ernesto De Martino e gli altri, ed. Riccardo Di Donato (Pisa: Edizioni ETS, 1990), 13.

114 Ulrich Van Loyen, "Die Abenteuer der Geister: Ernesto de Martino und die Anthropologien des besessenen Südens," in Der besessene Süden: Ernesto de Martino und das andere Europa, ed. Ulrich Van Loyen (Wien: Sonderzahl, 2016), 12.

115 De Martino, Vita di Gennaro Esposito, Napoletano, 25-27; Charuty, Ernesto de Martino, 58.
} 
he responds to the call of the times (appello dei tempi) by offering his contribution, which is a greater power of individuation, a preparation for a greater power for action." 116 In the case of the world of magic, which he encountered through his readings in ethnography, de Martino argued that some cultures were able to offer an appropriate response to the crisis. In short, he believed that magic operated by means of a dramatic process, which he called "dehistorification," which gradually led from the crisis to the "redemption of the presence" (il riscatto della presenza).

Further, the theory of de-historification not only addressed extra-European societies and the role that magic played therein, but also served as a conceptual tool to reevaluate the split scientific tradition of Western research on magic. First and foremost, de Martino used magic as a unifying idea for the discipline of religious studies. If he wrote earlier that "our civilization is in crisis," because it is "divided in separate entities ("compartimenti-stagni") and lacks [...] unity of thought,"117 he called magic the "unifying problem" that "could make apparent the artificial nature of the separation," and "break the boundaries of the empirical partitions of knowledge."118

The unity of our culture is essentially entrusted to unifying problems, which are, by means of their nature, apt to break the limits of the academic partitions of knowledge, which specialists sometimes mistakenly hold for determinations of things that exist in re. Thanks to their "connecting" function, they are apt to defeat the enduring influence of positivistic particularization and chipping. Now, the problem of the history of magic constitutes precisely one of these unifying problems. The historian, the philosopher, or the man of culture, who has nourished himself from the sources of modern humanism, finds the most favorable conditions for coming together with the psychological enthusiast, the psychiatrist, and generally any naturalistic thinker, on this ground. Here, he finds the conditions to pick up the "human" discourse, which seems to be interrupted since the period of romanticism, together with his colleagues. ${ }^{119}$

This unifying thrust of de-historification for the discipline of religious studies is best illustrated by means of a discussion of how de Martino engages in the works of two ideal types of the split discipline, namely Mircea Eliade and Claude Lévi-Strauss.

116 De Martino, Naturalismo e storicismo nell'etnologia, 57 .

117 De Martino, 56.

118 De Martino, Il mondo magico, 186.

119 De Martino, 5. 